\title{
PARASITE DIVERSITY OF ROCK PTARMIGAN IN ICELAND
}

\author{
Ute Stenkewitz ${ }^{1,2,3}$, Karl Skírnisson ${ }^{2}$, and Ólafur Karl Nielsen ${ }^{1}$ \\ ${ }^{1}$ Icelandic Institute of Natural History, Urriðaholtsstrati 6-8, P.O. Box 125,212 \\ Garðabar, Iceland. E-mail: ute@ni.is \\ ${ }^{2}$ Institute for Experimental Pathology, University of Iceland, \\ KELDUR, Vesturlandsveg, 112 Reykjavík, Iceland \\ ${ }^{3}$ Faculty of Life and Environmental Sciences, University of Iceland, \\ Askja, Sturlugata 7, 101 Reykjavík, Iceland
}

\begin{abstract}
The Icelandic Rock Ptarmigan (Lagopus muta) exhibits regular 10-year population cycles. Comparable population cycles are known for various species of northern herbivores, mammals, birds and insects. These multi-annual cycles are thought to be regulated by inter-population processes (e.g., interactions with food or predators or pathogens). Since 2006 studies have been conducted in NE-Iceland on the relation between the general condition of the birds and the population cycle. Condition factors studied were: parasite burden, body condition, stress levels, immunological defences and condition of the preen gland. The main questions have to do with the interrelation between these indices of the birds' health and whether these annual indices show a delayed density-dependent relation with ptarmigan numbers (expected lag 2-4 years). One part of these studies is to quantify the parasite fauna of the Rock Ptarmigan and get annual indices for the parasite burden. So far, 16 species of parasites have been identified: six species of endoparasites and 10 species of ectoparasites. Surprisingly, seven of those species were new to science and three were new host records. Received 25 January 2011, accepted 1 February 2011.
\end{abstract}

Stenkewitz, U., K. Skírnisson, And Ó. K. NiElsen. 2011. Parasite diversity of Rock Ptarmigan in Iceland. Abstract in R. T. Watson, T. J. Cade, M. Fuller, G. Hunt, and E. Potapov (Eds.). Gyrfalcons and Ptarmigan in a Changing World. The Peregrine Fund, Boise, Idaho, USA. http://dx.doi.org/10.4080/gpcw.2011.0130 